\title{
Karst and Pseudokarst of the West Kazakhstan (Republic of Kazakhstan)
}

\author{
Kazhmurat M. Akhmedenov ${ }^{1 *}$, Dinmuhammed Zh. Iskaliev², Vladim P. Petrishev ${ }^{3}$ \\ ${ }^{1}$ Scientific Research Institute of Biotechnology and Nature Management, West Kazakhstan Agrarian Technical University Named of \\ Zhangir Khan (WKATU), Uralsk, Kazakhstan \\ ${ }^{2}$ Department of Geography, M. Utemissov West Kazakhstan State University, Uralsk, Kazakhstan \\ ${ }^{3}$ Institute of Steppe (Ural Branch of RAS), Orenburg, Russian Federation \\ Email: "Kazhmurat78@mail.ru
}

Received December 25, 2013; revised January 23, 2014; accepted February 25, 2014

Copyright (C 2014 Kazhmurat M. Akhmedenov et al. This is an open access article distributed under the Creative Commons Attribution License, which permits unrestricted use, distribution, and reproduction in any medium, provided the original work is properly cited. In accordance of the Creative Commons Attribution License all Copyrights (C) 2014 are reserved for SCIRP and the owner of the intellectual property Kazhmurat M. Akhmedenov et al. All Copyright @ 2014 are guarded by law and by SCIRP as a guardian.

\section{ABSTRACT}

An analysis of the formation of karst and karst-suffosion forms on the territory of the West Kazakhstan region is presented in this paper. Numerous literary sources were used as the information database for the analysis of the relief features of the West Kazakhstan region. Evaluation of the morphometric features of the collapsed new formations on the basis of materials of our own field research is presented here for the first time. According to the research objectives there were defined localization places of the karst-collapsed phenomena where the reconnaissance field surveys were carried out. Survey points' localization has been carried out by means of GPS system with the help of 12-channel GPS-receiver of Garmin eTrex model. Geoinformational technology, based on MapInfo 9.5 and ArcGIS 9.2 packages was used for the building of the information and cartographic database. Original thematic maps compiled on the basis of the research results' analysis have been obtained in this research. The features of the Caspian Basin's karst landscapes, formed as a result of salt-dome tectonic manifestations (Inder Mountains, Malaya Bogdo Mountain, Bish-Chokho hill) are described in this paper. The important elements of the Caspian Basin salt-dome landscapes are landforms of the karst origin from large karst depressions of the karst-tectonic origin to modern forms of the sulfate karst: sinkholes, wells, polje, knobs ("Kurgantau”), arches, caves and grottoes. Some karst formations have a non-salt-dome origin. Three areas with the collapsed forms that have the karst-suffosion origin have been identified (near Konyr village, Berezovka village and Zhanatalap village). The mechanism of the sinkholes formation is due to the changes of the groundwater regime and the displacement of limestone eluvium as a result of active anthropogenic impacts. The sinkholes occurence near Zhanatalap village, which is located near the Karachaganak oil and gas field, is probably due to the anthropogenic initiation of karst-suffosion processes.

\section{KEYWORDS}

Geography; Geomorphology; Relief; Karst; Pseudokarst; Collapses; Suffusion; Denudation-Karst; Karst-Collapsing; Funnel; Ponor; Well; Trough; Keprok; Inder; Kazakhstan

\section{Introduction}

As it is known, the term "karst" is a set of specific landforms and features of the aboveground and underground hydrography, peculiar to certain areas, which have been formed by soluble subsurface rocks, such as rock salt, gypsum, limestone, dolomite etc.

\footnotetext{
"Corresponding author.
}

Karstic forms of relief can be randomly scattered on the surface of karstic massif or can be concentrated along the certain lines due to the direction of groundwater flow or due to the bedding of karstic rocks. These forms are not "frozen". They can transform from one into another. So, karstic saucer, as a result of deepening, and karstic well, as a result of flattening of slopes, can turn into sinkholes. If the walls of shakehole continue dissolving, 
the channel becomes large enough and turns into a natural well or natural mine. Karst shafts and wells often reach very large depths (tens or hundreds of meters). The forms like natural wells are often called natural wells, but of smaller size. Some researchers have fixed the term "well" for the certain forms, which are formed not because of superficial desalination, but by the collapse of the roof over the underground cavity. In such cases, the negative forms of the relief, having the cylindrical shape with vertical walls and cluttered bottom appear. Often, such wells are arranged in rows, as if marking on the surface a direction of the underground galleries, over which they were formed. When joining together, sinkholes or surface ponors form the blind ravines [1].

Karstic processes are associated with the dissolution of carbonate rocks, karst-suffosion processes-with the washing and removal of the filler from clayed and loamy earth cover, and the mechanical suffosion processeswith the removal of fine soil by groundwater from the sand rock mass and fractured limestone. They are often stimulated by the violation of geodynamic regime by the change of groundwater level due to pumping and appear on the surface as dishes, fissures, sinks etc. They become the most dangerous and difficult to predict events in the city's territory: to the formation of deep holes and uneven settling of different land surface parts.

Large forms of salt karst occurrence are called "karstic-collapsible troughs" and are known under different names in the literature: "disjunctive troughs", "leaching troughs”, “cavities of depression” etc. They spread in the eastern part of Caspian Lowland, and in other areas of the salt-bearing deposits.

A. E. Khod'kov [2] emphasized the differences in desalination of rock-salt and gypsum-anhydrite layers (and moreover carbonate rocks), which, apparently answer the question about the reasons of localization of some karstic-collapsible troughs exactly in the area of salt karst development. A. E. Khod'kov pointed that "the dissolution rate of rock salt is so much significant, that in case of roof of the bed dissolution by oversalt waters, an acaim of the saturated brine will occur over these beds". While the salt is present there, it is protected against the further solution by water.

Significant difference of water density with the different sodium chloride contents and a non-significant solution viscosity defines their extraordinary mobility, ability to move rapidly along the slope and to occupy the lowest spots. Small relief roof depressions of the salt beds begin to fill by brines, and the salt does not dissolve until the neighbouring areas are bleached and the brines are removed. As the result, the top of salt desalinization always happens as a slow ablation of salt beds' surface. Salt desalinization surface is a very slightly undulating surface which is the true boundary of the desalinization front, below which the saliferous rock remains completely undisturbed. Generally, for saliferous rocks, oversaline water encroachment towards the salt body is not typical. Salt karst under the influence of oversalt water is a superficial, shallow and usually represented by horizontal flat depressions in the top of salt [2]. It is obvious that neither in sulfate, nor in carbonate rocks there is no process development according to the scheme, described above. There is no potential for the formation of large karstic-collapsible troughs respectively.

\section{Materials and Methods}

We carried out the integrated geographical research of karstic-collapsible phenomena in West Kazakhstan region in 2012. Numerous literary sources have been used as the information base for the analysis of the relief features of the West Kazakhstan region [3-5]. Evaluation of the morphometric features of the collapsed neoformations on the basis of their own field research materials for the West Kazakhstan region is given for the first time.

In accordance with the research objectives there were defined the localization points of karstic-collapsible phenomena, where field reconnaissances had been carried out. Localization of survey points was carried out using GPS system with the 12-channel GPS-receiver of Garmin eTrex model. During the study there were used the geoinformational technologies on the basis of MapInfo 9.5 and ArcGIS 9.2 packages for the formation of informational-cartographic data base. The effects of studies were the original thematic maps that were based on the analysis of the research results.

Schematic map of karstic phenomena and processes expansion over the West Kazakhstan territory was drawn up on the basis of various literary sources [3-6], where there were descriptions of karstic relief effects within the region, and also descriptions of scientific expedition results in 2012 on the territory of Burlin and Syrym regions of WK. For making the hypsometric basis for this map there were used public data of satellite radar topographic mapping (SRTM) processed in ArcGIS 9.2. Morphological and morphometric descriptions of karst forms are available as per to results of the field geomorphological observations conducted during scientific expedition.

\section{Results and Discussion}

Considering the geology of the West Kazakhstan territory the karstic landforms effects in different parts are not so rare [3]. According to the karst zoning of Russian plain, the West Kazakhstan territory is almost entirely located in Nizhnevolzhsky-Uralsk karst region, which, in turn, is divided into Pre-Ural periclinal foredeep (northeastern part of the region) and into a larger province of Caspian syneclise. 
There is salt-dome tectonics at the boundary of Atyrau region, which is represented by the northern part of Inder uplift. Inder uplift, according to the above mentioned scheme zoning, geographically belongs to Inder-Emba district of the Caspian syneclise province. Western margin of the salt-dome is adjacent to the Ural River, and the eastern part stretches to Zhaltyrkol lake. Inder salt-dome region is a paradynamic conjugation, like five largest saltdome landscapes of Caspian Lowland, which consists of highly-karsted Inder mountains and large ellipsoidal Inder Lake, with the area of $115 \mathrm{~km}^{2}$ and the water's edge $-23 \mathrm{~m}$. below sea level (Figure 1 ).

The karst field of Inder Mountains is the largest in the Caspian Lowland. Total number of karstic forms runs up to 5000. Total value of surface reduction under the influence of karst processes is $1.87 \mathrm{~mm}$ /year. There are four types among the sinkholes-saucer-shaped, conical, ponor-shaped and the well-shaped. Saucer-shaped sinkholes, that are pervasive, but mostly on the periphery of Inder mountains, reach 10 - 15 m across diameter and 2 $3 \mathrm{~m}$ of depth. Conical sinkholes have $20 \mathrm{~m}$ of depth and 30 - $40 \mathrm{~m}$ across diameter. Ponor-shaped sinkholes have a conical shape with a narrow slit (ponor) in the bottom, that serves as a drainage channel. Karst wells have small sizes (up to $5 \mathrm{~m}$ in diameter), the depth reaches $15 \mathrm{~m}$. Some karst depressions and sinkholes are located in the south and south-east of Inder Lake.

S. S. Korobov and I. K. Polenov [6] single out a number of factors, that contribute to karst development over the Inder uplift:

1) The cap rock composition (gray medium-grained gypsum);

2) The cap rock fracturing (deep open fractures up to 10 - $16 \mathrm{~m}$ in depth and more);

3) Elevation of karstic massif above the base level of erosion (up to 35 - 40 m above Inder Lake);

4) Climatic characteristics (climate continentality and aridity, showers); karst is intensive in the period of snow melting and rain showers;

5) A low power of cover (Khvalynski) formations and their arenacaous (fine sandy loam and light loam) composition.

Morphological structure of Inder salt-dome landscape is complemented by a two-storied lake terrace that stretches along the southern and south-western coast. Inder denudation karst upland is, obviously, a relic of the ancient peneplain, which was first raised and eroded under the influence of salt tectonics, and then undergone the

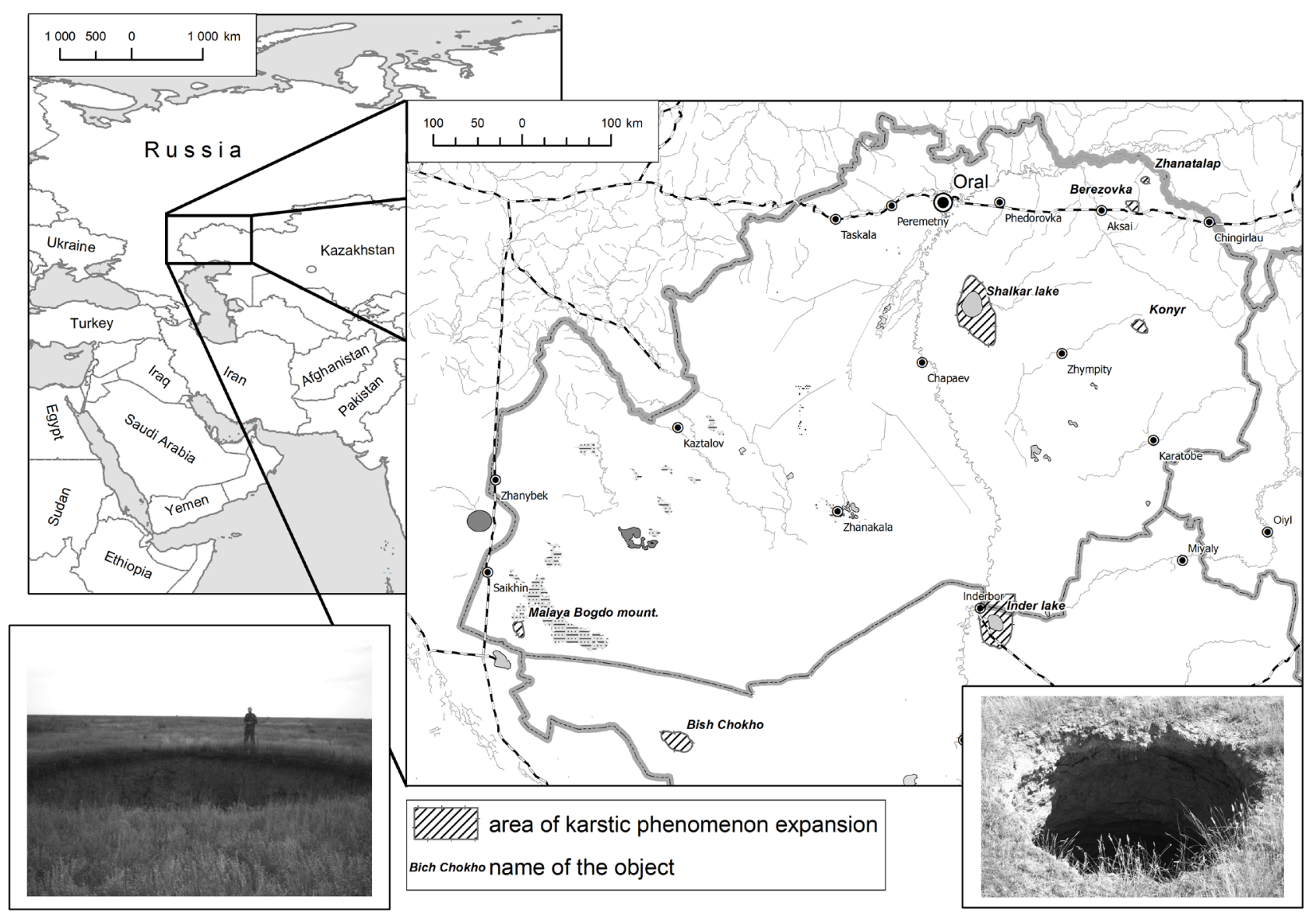

Figure 1. Karstic phenomenon and processes expansion in the West Kazakhstan territory. 
karst-denudation dissection with the formation of different micro-and mesoforms. Formation of the largest Inder karst field in Caspian Lowland is associated mostly with the secondary cap rock, which completely covers salt table of the dome with an area of $230 \mathrm{~km}^{2}$. Thickness of karst-tectonic breccia, which composes the cap rock, is about 50 - $60 \mathrm{~m}$. Cap rock consists of the rock salt, potash and potash-magnesium salts (halite, sylvite, carnallite, double manure salt), anhydrite and other rocks. In potash and potash-magnesium salts there is a boric mineralization (kaliborite, boracite, hydroboracite etc.) with the $\mathrm{B}_{2} \mathrm{O}_{3}$ in the rocks at the level of $1 \%-5 \%$.

Formation of secondary (karst-tectogenic) cap rock is associated with the wet postglacial epochs, and also with the leaching by sea water during the Caspian transgressions periods. The cap rock formation process led to the formation of various minerals, including unique: vitchite, gergeyite, hydroboracite, inderborite, inyoite, colemanite, kurnakovite, sulphoborite [6].

Inder dome cap rock is surrounded by fractured-karstic suprasalt waters. Inder cap rock has an extremely high filtration capacity: 300 - 500 l/day [6]. Aquifer recharge is performed by atmospheric precipitation and transit streams directed towards Inder Lake. 32 different springs crop out at the northern shore of the lake with the flow rates from hundredths portion of liters to several tens liters per second. The total flow rate of all springs is, at an average, $35.25 \mathrm{l} / \mathrm{sec}$ (or $1.1 \mathrm{million} \mathrm{m} /$ year). The most powerful is Aschebulak spring (22.5 l/sec).

Geomorphologic feature of Inder denudation-karstic hills is the differences between the north-western and south-eastern parts. If the north-western part of the upland represents an undulating plain, covered with many small sinkholes and depressions, the southeast surface is covered with ribbed ridges, which are the slopes of large karstic valleys and basins filled with the terrigenous deposits.

The forms of internal meso-and micro-relief are the characteristics of Inder Mountains, belonging to different altitude and genetic levels. The internal structure of the Inder Mountains' relief is determined mainly by salttable irregularities of the salt-dome uplift, which is complicated by diagenetic forms of the secondary salt tectonics (salt spikes and stems) and by forms of the underground and surface karstification.

There is a salt-dome mass of Malaya Bogdo mountain in the south-western part of the West Kazakhstan region (altitude is $37 \mathrm{~m}$ ), composed by the dislocated, fractured layers of ancient Palaeozoic and Mesozoic sedimentary rocks. Also the karst relief is widespread in this area, which is presented by the gypsum karst sinkholes.

The karst and caves of Bish-Chokho upland, in the neighboring Atyrau region, have been studied by I. V. Golovachev. Karstic caves on Bish-Chokho, as per the morphogenetic classification of V. N. Dublyansky, belong to the corrosion-erosion and to the corrosion-ruptural classes. Almost all caves are the sacciform cavities with a single entrance, in the gypsum cap rocks of saltdome.

During the speleological survey on the Bish-Chokho upland there was conducted a topographic survey of 10 discovered karstic caves that made it possible to determine their morphometric characteristics.

Except the above-mentioned karstic landforms, collapsed neoformations were revealed in Syrym and Burlin districts of West Kazakhstan region.

In early May 2009, in steppe, a hole in the ground has been detected at a distance of five kilometers to the north-west from Konyr village of the West Kazakhstan region. According to the WK Emergency department's data, a cenote with the size of $2 \times 3$ meters and with 2 meters of depth has been formed within two years. There is a crevice at the bottom of the cenote in the earth surface, with the width of $35-40 \mathrm{~cm}$, and with the depth inside the fault of 30 meters. The edges and walls of the crevice are smooth. Direction of the fault is from north to south. Radiation background is missing afield, no gas and other emissions from the crevice.

As per the information from Elena Arefina, a spokesman of the WK Emergency Situations Department (ESD), having studied the materials specialists of the RK Seismology Institute answered the WK ESD: "Wide dissemination of salt domes, which are determined by the local tectonic fractures, is common for Syrym region. The calcareous rocks (among which the karst landforms are usually formed) dominate in the sections of existing stratigraphic horizons that form the soil around the hole. Karstic phenomena occur against the tectonic fracturing, created by the widespread domes".

In June 2012, members of the Research Institute of the West Kazakhstan Agro-Technical University named of Zhangir Khan during scientific expedition in Burlin district of West Kazakhstan region found 3 holes in the ground near Berezovka village and the field of such holes near Zhanatalap village. It is worth noting that these places directly adjacent to the territory of Karachaganak oil and gas field. According to the karst zoning scheme of the Russian plain, this area geographically belongs to Inder-Emba district of Caspian syneclise province, Nizhnevolzhsko-Ural karst region.

The detected failures have the following morphological and morphometric features:

1) Sinkhole at Konyr village.

The sinkhole is located on the top of a hill from the edge of the bulk grader. Diameter is $2.6 \mathrm{~m}$, depth-3.2 $\mathrm{m}$. At the moment of examination the sinkhole was partially whelmed by adjoining ground and the motor car body was thrown into the sinkhole. The edge of the hole is 
sharp-cut, the borders are bold, and there are outcrops of limestone on the borders (presumably of Jurassic age). At south border of the sinkhole there is a hole with the size of $0.3 \mathrm{~m} \times 0.2 \mathrm{~m}$; the crevice's depth is more than $1 \mathrm{~m}$. The funnel is limited to the big bald patch, covered with boolgunyakh.

2) Sinkholes at Beryozovka village.

Sinkhole \#1. Diameter is $2.8 \mathrm{~m}$, the depth is $3.7-4.2$ $\mathrm{m})$, is a well with loam and with gypsum lenses. The borders are bold, diameter of the hole increases with the depth forming a pear-shaped form. The hole, according to local residents has occured in spring 2009. Potential reason is the dynamics of ground water level, caused by the rise of water level in reservoir on Berezovka River.

Sinkhole \#2. Diameter is $2.2 \mathrm{~m}$, depth is $3.8 \mathrm{~m}$; a well-shaped hole. As well as the first hole, the diameter increases with the depth by forming a pear-shaped form.

Sinkhole \#3. Cavity with the diameter of $6 \mathrm{~m}$, and the depth of $1.7 \mathrm{~m}$. In May 2009, a hole has appeared in Beryozovka village under the footing of a resident house. At present, the hole is backfilled.

3) Sinkholes' territory on the southwest of Zhanatalap v.

Number 1 sinkhole's diameter is $3.3 \mathrm{~m}$; depth is about $4 \mathrm{~m}$. Sinkhole number 2: diameter is $9.9 \mathrm{~m}$, depth is about 12 meters. Sinkhole number 3: diameter is $8.9 \mathrm{~m}$, depth: about $6 \mathrm{~m}$. Sinkhole number 4: diameter is $7.8 \mathrm{~m}$, the depth: about $6 \mathrm{~m}$. Sinkhole number 5 : diameter is 6.2 $\mathrm{m}$, depth: about $5 \mathrm{~m}$.

All sinkholes have the neatly-defined edges, the borders are bold (Figure 2). It is planned to set all sinkholes in one row, in meridional direction. According to information of Zhanatalap residents the sinkholes have appeared in spring 2009.

At present time there are three main working hypotheses for the holes genesis:

1) The holes are the results of karst-suffosion processes

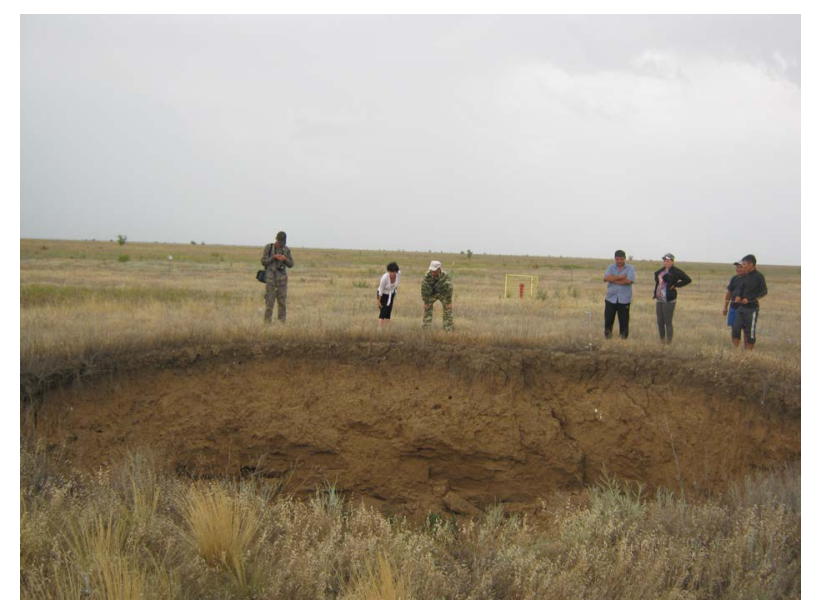

Figure 2. Collapsed neoformation near Zhanatalap village of Burlin district in WK. or pseudokarst manifestations due to natural reasons;

2) The holes are the manifestations of the salt dometectonics;

3) The holes are the results of surface soil disintegration caused by natural and man-made factors.

There are earth surface subsidence and collapse phenomena in areas of oil and gas production, where, together with oil approximately two volumes of groundwater are raised. Subsidence rate on some oil fields reaches $1-3 \mathrm{~cm} /$ year. Injection of fresh water into the earth's crust to maintain reservoir pressure in productive layers plays an important role in changing of oilfields' relief. For this purpose, rivers are often injected under the ground that leads to the activation of suffosion and karst processes [7]. Holes occurrence on the earth's surface is the potentially dangerous phenomena that is why the determination of their causes is crucial. The above mentioned question about the relation of sinkholes to saline-dome processess, expressed by the Seismology Institute scientists is controversial. The sinkhole has a basin-shaped form, such kind of a form is uncommon in the limestones, and a larger amount of precipitations is needed. In Syrym region of WK they are not enough. The domes are hosted at depth of 400 - $600 \mathrm{~m}$ - too deep for the aeration zone. Even if there are underground subsidences within the domes (they are common, for example, for Shalkar dome), then they are evident as big depressions (as synclines of subsidence on Aralsor). It is possible to fill the holes along the fracturing zone, but in this case it should be a series of sinkholes - a karst field. Even in more humid areas the limestone karst is evident as fractures and depressions. There is no continuous expansion of limestone; there is only a calciferous eluvium, which can migrate even under the influence of erosion and denudation processes. Sinkholes in the area of Karachaganak dome (near Zhanatalap village) relate to unloading zone of Akchagyl and Upper Jurassic aquifers. Moreover, the unloading takes place in the direction of Ilek River. All sinkholes are on one line directed from saliferous anticlinal core to its eastern side that comes to the Valley of Ilek River. Probably, the violation of horizons integrity due to man-made subsidences has caused the suffosion formations. The fact, that there are the wells with air intakes along the sinkholes, is confusing. This hardly could be the karst, because the depth of salt bedding is $200 \mathrm{~m}$; above them are jurassic limestones and above limestones are the Neogene and Quaternary light loam. The same is with sinkholes near Beryozovka village. They are also associated with the unloading of supra-salt horizons directed to the nearest stream flowBeryozovka village.

We came to the conclusion that sinkhole near Konyr village has the suffosion origin. It was formed along the strip where subsoil was raked for road. Thus, there is no 
direct relation to the salt tectonics neither in the first nor in the second, and nor in the third cases. Also we would like to note that the conclusions about genesis of the holes in Burlin and Syrym districts are preliminary, that is why determination of true causes for such hazardous to people and the civil engineering holes requires a thorough review.

\section{Conclusions}

Main conclusions on the karst and pseudokarst phenomenon of the West Kazakhstan come down to the following:

1) Karst processes in the West Kazakhstan are related to the salt-dome tectonics. Karst relief, represented by gypsum karstic sinkholes, is wide-spread on the saltdome landscape of the Prikaspian cavity (Inder Mountains, Malaya Bogdo and Bish Chokho).

2) Collapsed neoformations, discovered by us, have different origins, not connected with the salt-dome tectonics. The sinkhole of the Konyr village has the suffosion genesis which is conditioned by anthropogenic impact. The sinkholes formation near Berezovka, Konyr and Zhanatalap villages is connected with the unloading of oversaline horizons and the displacement of limestone eluvium caused by erosion and denudation processes.

3) The sinkholes formation at Zhanatalap village, which is located near to Karachaganak oil and gas field, possibly connected with technogenic matters due to the suffosion processes activization as a result of the field development.

\section{REFERENCES}

[1] D. S. Sokolov, "Main Conditions for Karst Development," GosGeolTechIzdat, Moscow, 1962, 323 p.

[2] A. E. Khod'kov, “The Processes of In-Situ Leaching of Salt and Gypsum-Anhydrite Rocks at Slavyansky Field and Their Manifestations on the Surface," Writings of All-Soviet Union Research Institute of Mineral-Salt Production No. 30, 1955, pp. 14-23.

[3] A. Z. Petrenko, "Natural-Resources Potential, and the Planned Projects of Reserve Fund of the West Kazakhstan Region," West Kazakhstan State University Named of Pushkin, Uralsk, 1998, 176 p.

[4] M. N. Sdykov, "Natural and Historical Sites of WK, Bokei Orda Region,” 2005, 146 p.

[5] I. V. Golovachyov, "Karst and Caves of Northern Prikaspy,” Publishing House of the ASTRAKHAN University, Astrakhan, 2010, 215 p.

[6] V. P. Petrishev, A. A. Chibilev, K. M. Akhmedenov and S. K. Ramazanov, "The Formation Features of Landscapes in the Inderskii Salt-Dome Area (Precaspian Hollow),' Geography and Natural Resources, Vol. 32, No. 2, 2011, pp. 146-151.

[7] A. G. Chikishev, "Natural Resources of Russian Plain in the Past, Present and Future," Publishing House "Nauka", Moscow, 1979, pp. 36-44. 